\title{
THE ROLE OF NEW INFORMATION AND COMMUNICATION TECHNOLOGIES IN THE PERFORMANCE OF PUBLIC RELATIONS (CASE STUDY: ELECTRONIC PAYMENT CARD NETWORK "SHAPARAK")
}

\author{
Farkhondeh Vosoghpour \\ Department of Social Communication Sciences, Ardabil Science and Research Branch, Islamic Azad \\ University, Ardabil, Iran \\ Ali Jafari \\ Department of Social Communication Sciences, Ardabil Branch, Islamic Azad University, Ardabil, \\ Iran \\ Jafari.communication@gmail.com
}

\begin{abstract}
The main objective of this study is the role of new information and communication technologies in the performance of public relations (case study of Shaparak network). This survey method is scrolling and measuring tool is a questionnaire. The statistical society of present research is shaparak's staffs that are 90 peoples based on Statistics. Sampling in this study were all counting. The results showed that the use of new information technologies and communication and information gathering is a significant relationship in public relations. This means that the use of new information technologies and communication, and public relations increases collecting information on public relations is also increasing. Also, between the use of new information technologies and communication and planning in public relations, there is a significant relationship. The use of new information technologies and communication and public relations there is a significant relationship, this means that the use of new information technologies and communication is increasing the communication in public relations is also increases. The results of this research also showed that the use of new information technologies and communication and public relations measurement and evaluation is a significant relationship. Today enabling information technology is raised as a tool for managers and employees. The electronic public relations can have played a key role as the information communication units in optimizing the information architecture process of organizations and this is true to Shaparak electronic payment card network.
\end{abstract}

Keywords: New technologies, Public relations, Shaparak, Communication, Performance, shaparak

\section{HALKLA İLIŞKILLER PERFORMANSINDA YENİ BILLGI VE İLETIŞIIM TEKNOLOJILLERININ ROLÜ (ÖRNEK OLAY: ELEKTRONIK ÖDEME KART AĞI "SHAPARAK")}

\section{ÖZ}

Bu çalışmanın temel amacı, halkla ilişkiler (shaparak ağının vaka çalışması) performansında yeni bilgi ve iletişim teknolojilerinin rolünü ortaya koymaktır. Çalışmada uygulanan anket yöntemiyle ölçümlemeler ve analizler yapılacaktır. Çalışmada yeni bilgi teknolojileri ve iletişim ve bilgi toplama kullanımı ve halkla ilişkilerle anlamlı bir ilişki olup olmadığı analiz edilecektir. Günümüzde pratik anlamda kolaylık sağlayan bilgi teknolojileri yöneticileri ve çalışanlar için etkileşimli bir araç olarak ortaya çıkmaktadır. Elektronik halkla ilişkiler kuruluşlarının bilgi mimarisi sürecini optimize bilgi 
iletişim birimleri olarak önemli bir rol oynamıştır ve bu rol ise örneklem olarak seçilen "Shaparak" elektronik ödeme ağı ile gösterilecektir.

Anahtar kelimeler: Yeni teknolojiler, Halkla ilişkiler, shaparak, Illetişim, Performans, shaparak

\section{INTRODUCTION}

The nature of public relations work is communication and public relations plays a role of communication. Public Relations and Communications are two concepts interdependent, communications is cause to birth public relations and public relations alive with Communications (Faghih, 2006). Given that the international community is moving towards the information society and everyone, without exception, have production facilities, distribution and use of information anywhere in the world, respectively, by entering this community public relations departments are forced to accept different roles. States, cities and organizations cause to create a public relations electronic. Manager of Public Relations in the third millennium should be able to understand the world around as an e-Citizen and proportional to the time, to train human resources under one roof and equipped with the tools needed to act. (Kohn, 1998)

Today's public relations went to go electronically and use of ICT quickly. Various Internet sites with all their strengths and weaknesses are managed by public relations. Contact with audience and people are very simple and easy through various means of information technology.

Dramatic changes in the field of information and communication technologies and the emergence of social networks and new media and advanced software production blogs and other ways of developing the use of ICT in public relations provided public relations groundwork for the development and diversification of services. Development of communications equipment and a variety of electronic tools, methods and relationship with the audience is not only easy and simple, but also with pushing the physical barriers between people and device is added on good communication.

In fact, IT construction has changed appearance and customer connect with an audience. In Iran observed that, the public relations have progressed rapidly since ICT has emerged and public relations practitioners on a good show to use it. Today an important part of people's daily contacts with organizations and people's organizations is done through a series of ICT tools. What is clear is that public relations using the "Information Technology" can maintain or enhance their own position. One of the main purposes to compose Shaparak is create the enabling environment for activities organizations that provide payment service that it would be appropriate guarantees to attract private sector participation in the development and leadership of the country's payment network and assist banking and monetary system in achieving sustainable development. This Company in first year of its activities in addition to receive the certification and qualification of the Supreme Council of Informatics ranking with looking at trade and scientific is the membership of organization of computer system and the Informatics Society of Iran. Due to having this backdrop purpose of this study is examines the role of new information and communication technologies in the performance of public relations (case study: Shaparak).

The theoretical framework includes a theory and theoretical concepts that researcher for the analysis and final conclusion of the research findings to use them. The theoretical framework includes of the theories and concepts of public relations and communications with the media the concept of social capital, media literacy, media satisfaction, and trust in the media.

Uses and gratifications theory: The belief that use of the media to happiness, need, desire or motivation depends on individual contacts almost have as soon as the research medium. Audience are formed often based on similar needs, interests and personal tastes that have social or psychological origin, this way of thinking belongs to the school of the " use or benefit or satisfaction and happiness. (Mac coil, 2004: 103-104). Uses and gratifications theory first article of the " Elihu Katz " (1959) was described. 
The evolution of uses and gratifications approach has the following three characteristics: First: as the media impact research to the attention of the media

Second, one of the reasons for the active use of the media and the audience knows Motivation

The third principle is based on uses, so it leaves no room for moral and political concerns and ignores moral judgments (Nico et al., 2003).

Take one-sided and one-dimensional on public relations staff and specific approach for explaining the relationship between social capital and its role in the interaction with the media through public relations practitioners it is inadequate to search for valid and scientifically can be examined public relations practitioners from different angles, because any practitioner of public relations with regard to the social, economic, cultural, educational and ..., where it flourished, a different look at the world around and out of itself, as well as an external media is out of this story.

With regard to the questions and hypotheses that were raised, theoretical framework can be explained as follows: each person in their dealings with the purpose of a particular medium; this may be the goal, as is without purpose or looking for something or look something specific. In this case, is to meet the needs of a medium is able to respond to them, in particular on the media (The idea use and satisfaction ) ; that's mean for example it going to be a hobby or want to make your time spent or purpose to business plans or special general awareness of the world around him or perhaps seek to meet the needs of personal identity or your social media brings the (theory of use and satisfaction ). Satisfaction of public relations professionals are discuss here from the media and also its relation to the interaction with the media. Media with resolve the public relations needs and expectations and meet the "expectations " cause to the "evaluation" positive, and thereby will continue establish the communication process and sometimes it happens that people have confidence in this process special media and in some cases going to happen upside down. That can be said at this time that trust in the media to play an effective role in the relationship with the media. As well as how to access, analyze and evaluate (the concepts of media literacy) employees as well as one of the most influential variables are taken in this study. This concept is kind and understanding the media. Media with resolve the public relations needs and expectations and meet the "expectations " cause to the "evaluation" positive, and thereby will continue establish the communication process and sometimes it happens that people have confidence in this process special media and in some cases going to happen upside down. That can be said at this time that trust in the media to play an effective role in the relationship with the media. ( Severin and Tankard, 2006 )

\section{METHODS AND MATERIALS}

This research of the purpose is practical and the wives of nature is descriptive and measurement survey. The population of a set of people, things and ... refers to a trait or characteristic in common(Baker, $2008: 170$ ). The statistical society of present research is shaparak's staffs that are 90 peoples based on Statistics. The sample group of individuals or members of the research community, represented by the community and the whole society has been more or less features. (Baker , 2008 : 171) In this study due to the small sample of the population studied all population and sampling all counts.

\section{FINDINGS}

According to data analysis can be said that 48 people $60 \%$ of respondents were male and 32 people equal to $40 \%$ were women. This indicates that the majority of respondents were men.

28 person Which were equivalent to 43.7 percent of respondents in the age group 30 to 35 years, 20 person were equivalent to 25 percent of respondents in the age group 36 to 40 years and 20 person were equivalent to 31.3 percent of respondents in the age group 41 to 45 years. So we can say that most respondents in the age group 30 to 35 years old. can be said that 24 people $30 \%$ of respondents 
were single and 56 people equal to $70 \%$ were married. This indicates that the majority of respondents were married.

can be said that 8 people equal of $10 \%$ of respondents have diploma and 16 people equal to $20 \%$ were bachelor, 56 people equal to $70 \%$ have Master's degree or higher This indicates that the majority of respondents have Master's degree or higher. Results data show that 72 people equal of $90 \%$ of believe that Shaparak public relations uses of all types of information and communications technologies while 8 people equal to $10 \%$ say no. It can be concluded that the majority of respondents believe that Shaparak public relations of all types uses of communication and information technologies.

\section{RESEARCH HYPOTHESES}

There is relationship between the use of new information technologies and communication and information gathering in public relations

Table 1 : Results of chi-square test to determine the relationship between the use of new information technologies and communication and Collecting information on public relations

\begin{tabular}{|c|c|c|c|c|}
\hline Test & Amount & $\begin{array}{c}\text { Degree of } \\
\text { freedom }\end{array}$ & Significance level & $\begin{array}{c}\text { Cramer } \\
\text { correlation } \\
\text { coefficient }\end{array}$ \\
\hline Chi 2 & 35.556 & 2 & 000 & 0.667 \\
\hline
\end{tabular}

The chi-square statistic and degrees of freedom is equal to 35.556 with a significance level of 0.000 is equal to 2 . The significance level is lower than 0.01 because the first hypothesis is confirmed with $99 \%$ confidence and $1 \%$ error. Therefore, there is a significant relationship between the use of new information technologies and communication and information gathering in public relations. The correlation Kramer coefficient of the two variables is equal 0.667. The correlation coefficient indicates a strong correlation between the two variables. According to the two-dimensional table above the use of new information technologies and communication is increases collecting information on public relations is also increasing.

There is relationship between the use of new information technologies and communication and planning in public relations

Table 2 : Results of chi-square test to determine the relationship between the use of new information technologies and communication and Planning in Public Relations

\begin{tabular}{|c|c|c|c|c|}
\hline Test & Amount & $\begin{array}{c}\text { Degree of } \\
\text { freedom }\end{array}$ & Significance level & $\begin{array}{c}\text { Cramer } \\
\text { correlation } \\
\text { coefficient }\end{array}$ \\
\hline Chi 2 & 43.547 & 3 & 000 & 0.682 \\
\hline
\end{tabular}

The chi-square statistic and degrees of freedom is equal to 43.547 with a significance level of 0.000 is equal to 3 . The significance level is lower than 0.01 because the first hypothesis is confirmed with $99 \%$ confidence and $1 \%$ error. Therefore, there is a significant relationship between the use of new information technologies and communication and new information and planning in public relations. The correlation Kramer coefficient of the two variables is equal 0.682 . The correlation coefficient indicates a strong correlation between the two variables. According to the two-dimensional table above the use of new information technologies and communication is increases planning on public relations is also increasing.

There is relationship between the use of new information technologies and communication and communication in public relations 
The Turkish Online Journal of Design, Art and Communication - TOJDAC April 2016 Special Edition

Table 3: Results of chi-square test to determine the relationship between the use of new information technologies and communication and communication in Public Relations

\begin{tabular}{|c|c|c|c|c|}
\hline Test & Amount & $\begin{array}{c}\text { Degree of } \\
\text { freedom }\end{array}$ & Significance level & $\begin{array}{c}\text { Cramer } \\
\text { correlation } \\
\text { coefficient }\end{array}$ \\
\hline Chi 2 & 70.000 & 3 & 000 & 0.894 \\
\hline
\end{tabular}

The chi-square statistic and degrees of freedom is equal to 70.000 with a significance level of 0.000 is equal to 3. The significance level is lower than 0.01 because the first hypothesis is confirmed with $99 \%$ confidence and $1 \%$ error. Therefore, there is a significant relationship between the use of new information technologies and communication and new information and communication in public relations. The correlation Kramer coefficient of the two variables is equal 0.894 . The correlation coefficient indicates a strong correlation between the two variables. According to the two-dimensional table above the use of new information technologies and communication is increases communication on public relations is also increasing.

There is relationship between the use of new information technologies and communication and evaluation and measurement in public relations

Table 4: Results of chi-square test to determine the relationship between the use of new information technologies and communication and evaluation and measurement in Public Relations

\begin{tabular}{|c|c|c|c|c|}
\hline Test & Amount & $\begin{array}{c}\text { Degree of } \\
\text { freedom }\end{array}$ & Significance level & $\begin{array}{c}\text { Cramer } \\
\text { correlation } \\
\text { coefficient }\end{array}$ \\
\hline Chi 2 & 20.741 & 2 & 000 & 0.509 \\
\hline
\end{tabular}

The chi-square statistic and degrees of freedom is equal to 20.741 with a significance level of 0.000 is equal to 2 . The significance level is lower than 0.01 because the first hypothesis is confirmed with $99 \%$ confidence and $1 \%$ error. Therefore, there is a significant relationship between the use of new information technologies and communication and new information and evaluation and measurement in public relations.

The correlation Kramer coefficient of the two variables is equal .509. The correlation coefficient indicates a strong correlation between the two variables. According to the two-dimensional table above the use of new information technologies and communication is increases evaluation and measurement on public relations is also increasing.

\section{CONCLUSION:}

his study has been done with purpose of " the role of new information and communication technologies on the performance of public relations (Shaparak case study ) ", that the results of which are as follows :

Studies showed that 90 percent of respondents believe that public relations Shaparak uses of all types of communication and information technologies, $90 \%$ of respondents stated that the use of new information and communication technologies in Shaparak public relations high and very high cause to two-way communication, 80 percent of respondents believe that the use of new information and communication technologies in Shaparak public relation in high and very high levels can reduce costs and increase employee productivity rate, , 50 percent of respondents believe that the use of new information and communication technologies in Shaparak public relations in high and very high levels can cause instant access to information. 50 percent of respondents believe that the use of new information and communication technologies in Shaparak public relations to somewhat can be reduced the volume of official letters and archives, 50 percent of respondents believe that the use of new information and communication technologies in Shaparak public relations to largely deletes unskilled managers in the field and replaces those fluent in these technologies. 
In a world full of change and competition today that all aspects of the passage of time that all things quickly becomes stale, only the survival of communities and organizations, and will be successful in their activities, that the infusion of the universal knowledge into value-added act in format of live in informational systems such as the Internet and intranet and with similar organizations and networks active relationships established production and distribution of their information.

It is natural that in this respect, organizing specialized agency is responsible for and in charge of the organization of "public relations".

The results showed that the use of new information technologies and communication and information gathering is a significant relationship in public relations because as the use of new information technologies and communication, and public relations increases collecting information on public relations is also increasing. Also, between the use of new information technologies and communication and planning in public relations, there is a significant relationship because as the use of new information technologies and communication, and public relations increases planning on public relations is also increasing.

The use of new information technologies and communication and public relations there is a significant relationship, because as well as the use of new information technologies and communication is increasing the communication in public relations is also increases.

The results of this research also showed that the use of new information technologies and communication and public relations measurement and evaluation is a significant relationship because as well as the use of new information technologies and communication, and public relations increases measurement and evaluation on public relations is also increasing.

The dramatic developments during this public relations can be a link between the institutions and organizations in society as well as linking of cultures, traditions and views Its main element communities, nations, the world's mentality pulse. In such a view the situation of public relations, subscribe to receive the information in the information society, cannot merely wait for a statement or report writing, public relations official. Public Relations in the virtual world needs a new definition, otherwise public relations agencies merely administrative or reference secretariat to record and expectations of turns.

Nowadays, information technology is raised as a means of empowerment for managers and employees. In this among the electronic public relations as communication units can have key role in optimizing the information architecture process in organizations.

\section{RESEARCH SUGGESTIONS}

Public relations should take note of the following:

1. The use of new information and communication technologies in public relations rather than official letters.

2. The use of new information and communication technologies in public relations to reduce costs.

3. The use of new information and communication technologies in public relations for an increase employee productivity rate.

4. The use of new information and communication technologies in public relations for quick access to information.

5. Setting up blogs and podcasts and odcasts, forum and RSS systems

6. Organize news ( information seeking and striving for timely notification methods and communication tools ).

7. Developing a coherent communication system and clear and transparent advertising.

8. Active and Continued cooperation with the media and press. 


\section{REFERENCES:}

Araste Kani, H.(2007). Research trends in social communication, MA thesis of the field of communications,Supervisor Dr. Mohammed Soltanifar, Advisor Dr. Nastaran. Khajehnoori, Islamic Azad University.

Asadzade shahir, Hasan.(2007). The success rate of government office public relations ofTabriz city, MA thesis, the field of communications, research trends in social communication, Islamic Azad University.

Baker Trezal.( 2008). How do social research, translated by H. Nayebi, Tehran : Ney Publishing Khoynezhad, Gholamreza . (2002 ). Methods of Research in Behavioral Sciences, Tehran: Samt Publishing.

Severin , Werner and James Tankard .(2006 ). Communication theory, translated by A. Dehghan, Tehran : Tehran University Press.

Faghih, M.A .(2006). Effectiveness in communication and public relations (Review of concepts and methods), Publisher: Shahed Press.

Cohen, Paula Marantz .( 1998). A course on public relations, translation by Khamoshi and Mir Saeed Ghazi, Tehran: Office of Media Development.

Mac Quayle, D .(2004 ). Introduction to the theory of mass communication, translation of M. Montazerghaem, Tehran : Centre for Research and Media Studies

Mehrdad. , H. (2002 ). Introduction to the ideas and concepts of mass communications , Tehran : Publication of Pharan

Momeni noorabadi, M. (2002-2003). PR electronics and its future in Iran, MSc thesis, the field of communications, research trends in social communication, Islamic Azad University.

Niko, M and et al. (2001), Understanding the TV audience with uses and gratifications approach, Tehran : Soroush.

Webster, F. (1382 ). Theories of the Information Society, translated by Mehdi Davoudi, Tehran , publisher of the Ministry of Foreign Affairs. 